\title{
Seni Kerajinan Sarana Upacara Berbasis Upcycle Di Desa Kediri Tabanan
}

\author{
Ni Kadek Karuni ${ }^{1}$, I Wayan Mudra ${ }^{2}$, Mercu Mahadi $^{3}$ \\ ${ }^{1}$ Program Studi Kriya , Fakultas Seni Rupa dan Desain, Institut Seni Indonesia Denpasar, Indonesia
}

${ }^{1}$ kadekkaruni8@gmail.com

\begin{abstract}
Seni kerajinan sarana upacara yang memanfaatkan media koran bekas saat ini baru mulai berkembang dibeberapa daerah di Bali. Penggunaan koran bekas untuk menciptakan produk kerajinan merupakan suatu trobosan baru dari perajin dalam mengembangkan kreativitas menciptakan produk kerajinan yang lebih bervariatif. Pemikiran ini sesuai dengan konsep upcycle atau dalam proses perlakuannya disebut upcycling adalah proses pengubahan limbah bahan atau produk yang tidak berguna menjadi bahan baru atau produk dengan kualitas lebih baik untuk keberlanjutan dan profitabilitas. Bagaimana dinamika bentuk produk sarana upacara berbasis upcycle, serta proses kreatif perajin dalam memanfaatkan limbah koran sebagai media seni kerajinan sarana upacara yang dapat mendukung kegiatan adat dan agama Hindu di Bali? Tujuan penulisan ini adalah untuk menjelaskan tentang dinamika bentuk produk seni kerajinan sarana upacara berbasis upcycle yang dihasilkan oleh perajin di desa Kediri Tabanan serta proses kreatif perajin dalam menciptakan produk sarana upacara. Penelitian ini menggunakan metode deskriptif kualitatif, dengan teori pengambilan sampel porposive sampling, Metode pengumpulan data melalui observasi, wawancara, dokumentasi, dan analisa data secara kualitatif dengan menggunakan teori pendekatan estetika dan pendekatan Agama. Berdasarkan hasil analisis menunjukkan bahwa proses pembuatan produk sarana upacara ini menggunakan teknik pilin, penerapan dekorasi menggunakan teknik pilin dan tempel, finishing menggunakan teknik oles. Bentuk produk berupa : bokoran, tempat pemuspan, keben, Dulang, berbahan dasar koran bekas yang fungsinya sebagai wadah atau tempat sesajen. Produk yang dihasilkan merupakan produk kreatif yang ramah lingkungan. Kesimpulannya adalah proses membuatan produk kerajinan sarana upacara melalui proses pembentukan, pendekorasian dan tahap finishing. Pemanfaatan limbah koran untuk produk kerajinan sarana upacara merupakan suatu upaya untuk mengurangi pencemaran lingkungan. Selain itu pemanfaatan limbah koran sebagai bahan seni kerajinan dapat meningkatkan nilai tambah dan nilai ekonomi perajin.
\end{abstract}

Kata kunci : Kerajinan, Upcycle, Sarana Upacara, nilai tambah

\section{The Art Of Upcycle-Based Ceremonial Means In Kediri Tabanan}

The art of ceremonial means utilizing the use of newspapers is now just starting to develop in some areas of Bali. The use of newspapers to create handicraft products is a new breakthrough from crafters in developing creativity to create more diverse handicraft products. This thought which is in line with the upcycle concept or upcycling, regarding its process, is the process of converting waste materials or products that are not useful into new materials or products with better quality for sustainability and profitability. How are dynamics forms of upcycle-based ceremonial products, as well as creative process of craftsmen in utilizing newspaper waste as a means of art ceremonial craft that could support traditional and ceremonial activities of Hindu in Bali? The purpose of this paper was to explain dynamics forms of upcycle-based ceremonial craft products produced by craftsmen in Kediri Tabanan as well as the creative process of the crafters in creating ceremonial means products. This study used descriptive qualitative methods, with purposive sampling techniique. Data collection was conducted through observation, interviews, documentation, and The data were analyzed by qualitative data analysis using aesthetic approach and religion approaches. Based on the results of the analysis, it showed that the process of creating ceremonial means products used a stranded technique in which the application of decorations used a stranded and paste technique; meanwhile, the finishing process used a topical technique. The form of products are in the forms of: bokoran, pemuspan, keben, Dulang, made from newspapers which are functioned as a container or place of offerings. The product produced is an environmentally friendly creative product. In conclusion, the process of making craft products ceremonial means was through the process of forming, decorating and finishing stages. Utilization of newspaper for ceremonial craft products was an effort to reduce environmental pollution. Furthermore, the use of newspaper as a craft material can increase 
the added value and economic value of the craftsman.

Keywords: Craff, Upcycle, Ceremony Means, Added value

Proses Review : 1 - 20 Mei 2020, Dinyatakan Lolos: 29 Mei 2020

\section{PENDAHULUAN}

Membuat produk kerajinan merupakan budaya yang telah lama berkembang di Bali. Aktivitas budaya tersebut pada awalnya hanya merupakan tradisi masyarakat di beberapa desa yang hasilnya sebagian besar untuk memenuhi kebutuhan masyarakat di lingkungan desa tersebut. Pada saat ini aktivitas membuat produk kerajinan tidak hanya menjadi pekerjaan sampingan atau pengisi waktu luang tetapi ditekuni sebagai mata pencaharian dan bahkan telah berkembang menjadi masyarakat kreatif.

Terdapat berbagai macam jenis kerajinan yang berkembang di Bali, antara lain; seni kerajinan yang menggunakan media bambu, kayu, rotan, logam, dan fiber glass. Kemampuan dan kreativitas perajin yang semakin berkembang turut mempengaruhi perkembangan jenis kerajinan di Bali. Pada saat ini mulai berkembang seni kerajinan terbuat dari koran bekas untuk sarana (wadah) upacara. Para perajin memanfaatkan koran bekas untuk benda kerajinan tersebut dengan berbagai variasi bentuk, jenis dan fungsinya. Upaya tersebut sesuai dengan penerapan konsep upcycle, yakni suatu upaya meminimalisir dampak buruk limbah dengan memanfaatkan limbah bahan atau produk yang tidak berguna menjadi produk baru dengan kualitas yang lebih baik. Upcycle atau yang disebut juga upcycling adalah proses pengubahan limbah bahan atau produk yang tidak berguna menjadi bahan baru atau produk dengan kualitas lebih baik serta untuk menjaga kelestarian lingkungan (Hyun Joo, 2014: 175). Hal ini merupakan sebuah pemikiran kreatif yang dilakukan oleh para perajin sarana upacara saat ini.

Pemanfaatan limbah koran yang diolah kembali menjadi sebuah produk baru dapat dipandang sebagai langkah yang mendatangkan keuntungan. Keuntungan yang dimaksud bukan hanya dari segi ekonomi tetapi juga memberi dampak posistif bagi lingkungan. Limbah koran kalau tidak dimanfaatkan akan menjadi sampah yang dapat mencemari lingkungan. Dengan konsentrasi dan kuantitas tertentu, kehadiran limbah dapat berdampak negatif terhadap lingkungan terutama bagi kesehatan manusia, sehingga perlu dilakukan penanganan terhadap limbah (Pradnyani,2019: 4). Limbah koran justru dapat dimanfaatkan atau didaur ulang oleh perajin yang kreatif sehingga menghasilkan sebuah produk baru dan memberi efek finansial serta sebagai upaya meminimalisir pencemaran terhadap lingkungan. Demikian halnya yang telah dilakukan oleh perajin di banjar Pande desa Kediri Tabanan. Terciptanya karya kreatif berupa produk kerajinan sarana upacara dapat dipandang sebagai salah satu upaya penyelamatan lingkungan.

Kesadaran menjaga lingkungan hidup dengan meminimalkan dampak buruk limbah koran ini tanpa sadar telah digeluti perajin di desa Kediri Tabanan. Hal ini tentu sesuai dengan tujuan upcycling yaitu mengubah limbah atau produk yang tidak berguna menjadi bahan baru atau produk dengan kualitas lebih baik serta memiliki fungsi yang lebih dari fungsi sebelumnya.

Metode upcycle menjadi keunggulan dalam proses menciptakan produk sarana upacara. Kenyataan itu yang telah mendorong keinginan peneliti untuk meneliti dan mengetahui lebih jauh tentang berbagai hal mengenai penerapan konsep upcycle pada seni kerajinan sarana upacara di desa Kediri Tabanan

Dari fenomena yang dipaparkan di atas, ada beberapa permasalahan yang perlu dibahas dalam penelitian ini yaitu; Bagaimana dinamika bentuk produk sarana upacara berbasis upcycle yang dapat mendukung kegiatan adat dan agama hindu pada masyarakat Bali? 2. Bagaimana proses kreatif perajin dalam memanfaatkan limbah Koran sebagai media seni kerajinan sarana upacara?

Penelitian ini dilakukan dengan tujuan agar dapat mengetahui dinamika bentuk produk sarana upacara berbasis upcycle yang berkembang di Banjar Pande desa Kediri Tabanan yang dapat digunakan oleh masyarakat dalam melakukan aktivitas upacara adat dan agama. Selain itu penelitian ini juga dilakukan guna mengetahui secara mendalam proses kreatif perajin dalam memanfaatkan limbah koran sebagai media kerajinan sarana upacara yang ramah lingkungan. serta dapat meningkatkan produktivitas perajin di banjar Pande desa Kediri Tabanan. Melalui penelitian ini diharapkan dapat memberikan informasi pada masyarakat dan pemerintah bahwa seni kerajinan sarana upacara berbasis upcycle perlu tetap dikembangkan dengan berbagai kreasi dalam usaha mendukung gaya hidup religius masyarakat Bali. Hasil penelitian ini akan sangat bermanfaat bagi kalangan akademik seni rupa khususnya seni kriya sebagai sumber studi pembelajaran, terutama dalam penciptaan karya yang berbasis upcycle, sehingga dapat menjaga kelestarian lingkungan. 


\section{KAJIAN SUMBER}

\section{Limbah Koran}

Limbah atau Sampah merupakan hal kecil yang sering dilupakan, namun dapat menjadi masalah yang sangat besar apabila tidak ditangani secara serius (Azwar, 1990). Mendengar kata sampah mungkin hal yang ada dibenak kita hanyalah benda kotor dan tidak berguna. Namun anggapan seperti itu tidak selalu benar, sampah dapat dimanfaatkan menjadi barang yang bernilai jual tinggi dan menguntungkan (Suprihana, 1997). Kertas koran merupakan bahan yang selalu diproduksi untuk keperluan media cetak dan dikonsumsi oleh sebagian masyarakat Indonesia dalam setiap harinya yang kemudian menghasilkan limbah kertas koran bekas. Limbah ini sebenarnya dapat dimanfaatkan untuk berbagai keperluan dan mempunyai nilai ekonomi bagi yang mempunyai kreasi mengubah bahan limbah kertas koran menjadi bentuk produk daur ulang tertentu.

Penelitian terkait dengan limbah koran memang sudah cukup banyak dilakukan, namun sebagian besar penelitian mengarah pada pemanfaatan limbah koran sebagai campuran bahan lain, misalnya penelitian yang dilakukan oleh Sarito, dkk, dengan judul; Limbah Koran Sebagai Bahan Campuran Pembuatan Papan Plafon. Penelitian ini difokuskan pada pembuatan campuran bubur koran untuk memperoleh bahan pengganti penutup plafon dari bahan gypsum (Sarito,2017:77) Ismail Alif Siregar dalam jurnal Universitas Pembangunan Jaya (UPJ), melakukan penelitian tentang Pemanfaatan Limbah Koran Untuk Pengembangan Material Bahan Fiber. Penelitian ini fokus terhadap eksplorasi dan pengembangan potensi limbah koran sehingga memiliki nilai produk yang tinggi dan membawa dampak yang sangat besar bagi industri produk. ( Ismail Alif Siregar, 2015:142). Sedangkan penelitian tentang kerajinan yang mengkhusus mengenai seni kerajinan sarana upacara berbasis upcycle di desa Kediri kecamatan Kediri Tabanan belum pernah dilakukan oleh peneliti lain. Penelitian ini khusus akan membahas pemanfaatan limbah koran sebagai medium pembuatan produk kerajinan sarana upacara yang berkaitan dengan teknik penciptaan, bentuk dan minat masyarakat terhadap produk kerajinan sarana upacara yang dihasilkan oleh perajin di banjar Pande Desa Kediri Tabanan. Selain beberapa penelitian mengenai limbah koran di atas, juga akan dikaji beberapa pendapat akademisi, budayawan dan pengusaha berkaitan dengan perkembangan seni kerajinan yang ada, dan akan digunakan sebagai pendukung validitas analisis data.

\section{Seni Kerajinan}

Seni kerajinan merupakan bagian dari seni rupa yang telah bereksistensi di sepanjang sejarah kehidupan manusia. Seni kerajinan hadir dalam masyarakat karena diperlukan dalam berbagai bentuk kehidupan praktis masyarakat. Dengan demikian keberadaannya tidak hanya merupakan bentuk pernyataan seni, akan tetapi merupakan manifestasi kehidupan masyarakat pendukungnya. (Umar Kayam ,
1982: 37). Bahkan kehadiran produk seni kerajinan menjadi sarana penting yang dapat memperlihatkan status seseorang atau menjadi sarana legitimasi. Selain itu kehadiran seni kerajinan juga telah menjadi materi perdagangan yang dapat mendatangkan devisa bagi perkembangan perekonomian bangsa. Sp. Gustami,1999; 5). Hal itu karena bidang seni kerajinan memiliki kandungan nilai-nilai sosial, ekonomi, budaya, spiritual dan material (Sp. Gustami, 1999 : 2)

Seni kerajinan merupakan salah satu karya seni yang tak dapat dipisahkan dari kehidupan masyarakat Bali. Seni kerajinan telah melekat erat dengan masyarakat Bali yang dimanfaatkan dalam segala aktivitasnya, baik yang berhubungan dengan kebutuhan hidupnya sehari-hari maupun untuk kebutuhan spiritual senantiasa memanfaatkan seni kerajinan sebagai instrumennya. Dengan demikian keberadaannya tidak hanya merupakan bentuk pernyataan seni, akan tetapi merupakan manivestasi kehidupan masyarakat pendukungnya (Kayam, 1981/1982: 37). Bahkan kehadiran produk seni kerajinan menjadi sarana penting yang dapat memperlihatkan status seseorang atau menjadi sarana legitimasi. Seni kerajinan yang sarat dengan nilainilai estetika serta memantulkan pesona keanekaragaman budaya nusantara, tampak semakin digemari masyarakat manca Negara dan menjadi salah satu produk yang memberi andil dalam peningkatan pemasukan devisa Negara. Kesadaran berkesenian masyarakat Bali telah mengental dan mentradisi dalam setiap gerak kehidupannya, seni dijadikan sebagai sistem nilai untuk menghayati makna dalam kehidupan beragama dan bermasyarakat. Kristalisasi ide vital dalam seni merupakan fikiran konseptual yang dijadikan isi normative mengacu pada nilai yang dianut masyarakat (Karma Yudibrata, 1982: 103). Kelangsungan aktivitas berkesenian dalam kehidupan masyarakat Bali tidak berdiri sendiri, akan tetapi selalu berkaitan dengan agama, adat istiadat, mata pencaharian dan perekonomian masyarakat. Karya seni yang tercipta merupakan ekspresi bermatra individual, sosial dan budaya, mengandung makna yang berkaitan dengan berbagai tema, interpretasi atau pengalaman hidup. (Tjetjep Rohendi Rosidi,2000: 16).

Demikian juga halnya dengan situasi masyarakat Bali saat ini yang banyak membutuhkan produk kerajinan sarana upacara dengan berbagai bentuk dan fungsi merupakan peluang yang sangat terbuka bagi perajin untuk meningkatkan kreativitasnya dalam usaha mendukung gaya hidup masyarakat yang semakin konsumtif. Seni kerajinan sarana upacara merupakan salah satu seni kerajinan Bali yang pada saat ini memiliki peluang yang sangat besar untuk dikembangkan di tengah-tengah peningkatan orientasi masyarakat yang lebih memperhatikan spiritual dalam proses kehidupannya. Meningkatnya aktivitas upacara agama dan adat serta rekreasi religius masyarakat Bali, memerlukan berbagai bentuk dan jenis sarana upacara yang unik dan artistik. Hal ini menjadi peluang yang sangat terbuka bagi perajin untuk berkreasi lebih inovatif 
dalam berkarya. Perajin sangat jeli untuk menciptakan sesuatu yang berbeda dan sesuai dengan selera masyarakat. (Karuni, Suardana, 2018: 163). Salah satunya dengan mengolah limbah koran menjadi produk sarana upacara yang menarik dan indah.

\section{Upcycle}

Semakin banyaknya kebutuhan manusia akan produk untuk dikonsumsi menimbulkan berbagai dampak terhadap lingkungan terutama limbah bahan yang tidak dapat terurai. Fenomena ini yang memunculkan seni mendaur ulang, dapat dikatakan seni karena dalam prosesnya memerlukan tingkat kreatifitas untuk dapat mengolah dan menghasikan produk baru dari hasil daur ulang. Proses daur ulang dengan cara upcycling.

Kyungeun Sung dengan judul penelitian A Review on Upcycling: Current Body of Literature, Knowledge Gaps and a Way Forward (2015) membahas mengenai berbagai literatur tentang upcycle dan kemajuan yang ditawarkan melalui konsep upcycle. Hal ini berkaitan dengan penelitian yang juga membahas mengenai produk hasil dari proses upcycling.

Pintu Pandit dengan judul penelitian Upcycle and LowCost Sustainable Business for Valueadded Textiles and Fashion (2019) membahas mengenai upcycle yang merupakan alternatif untuk menghasilkan produk baru, juga sebuah cara menjaga lingkungan yang memiliki profitabilitas. Relevansi buku ini dengan penelitian adalah adanya penjelasan mendalam mengenai upcycle dan cara penerapannya dalam dunia tekstil serta dampak yang diperoleh baik dari segi keuntungan atau profit bisnis maupun dampaknya terhadap lingkungan. Walaupun penelitian ini membahas upcycle pada tekstil dan fashion, namun ada kemiripan dengan penelitian kerajinan ini dilihat dari penerapan metode upcycle. Dan juga dilihat dari objek produk sarana upacara sebagai produk yang berasal dari kreativitas perajin di banjar Pande Desa Kediri memanfaatkan bahan limbah menjadi produk baru yang mendatangkan profit.

Semua pendapat dan hasil penelitian diatas digunakan sebagai pedoman ilmiah untuk melihat, membahas dan menguraikan persoalan persoalan penelitian tentang seni kerajinan sarana upacara berbasis upcycle di banjar Pande desa Kediri Tabanan.

\section{METODE PENELITIAN}

Penelitian ini dilakukan di lingkungan Banjar Pande Desa Kediri Tabanan. Pemilihan lokasi penelitian karena perajin di desa ini mengembangkan dan memproduksi sarana upacara berbahan limbah koran. Objek penelitiannya meliputi seluruh produk sarana upacara yang diproduksi oleh perajin di Banjar Pande Desa Kediri Tabanan. Dari jumlah populasi tersebut, kemudian dipilih produk berdasarkan penerapan metode upcycle.

Penelitian ini menggunakan metode kualitatif yaitu pengamatan, wawancara, dan penelaahan dokumen. Metode ini digunakan karena lebih mudah berhadapan dengan kenyataan, menyajikan secara langsung hubungan antara peneliti dan responden, lebih peka dan lebih dapat menyesuaikan diri pola-pola nilai yang dihadapi (Moleong, 2013: 10). Teknik Pengumpulan data penelitian secara maksimal ditempuh melalui studi pustaka, observasi, wawancara, dan dokumentasi. Selain itu sumber data lainnya diperoleh melalui buku, jurnal, artikel,catatan, dan dokumen. Analisis data meliputi berbagai tahapan: Pertama identifikasi data, mengumpulkan data verbal dan data visual, baik yang diperoleh melalui studi pustaka, observasi, maupun wawancara. Kedua klasifikasi data yaitu memilih atau mengelompokkan data yang telah teridentifikasi sesuai dengan jenis dan sifat data. Ketiga seleksi data yaitu menyisihkan data-data yang tidak relevan dan kurang berkontribusi terhadap kebutuhan dalam pembahasan pokok. Tahap keempat melakukan analisis sesuai dengan teori yang telah ditetapkan, dengan menggunakan analisis kualitatif analitik. Kajian dilakukan dengan pendekatan Estetika berdasarkan pada teori Fildman dan pendekatan Agama berpikir berdasarkan keyakinan (keimanan) berkaitan dengan istilah yang lazim digunakan dalam agama Hindu yang berkaitan dengan penggunaan sarana upacara yaitu Sukla, Cemer, Suci dan Leteh.

\section{PEMBAHASAN}

Penggunaan limbah Koran sebagai sarana upacara, menjadi perhatian khusus masyarakat. Hal ini dikarenakan sarana upacara berbahan limbah yang dianggap kotor, leteh, cemer. Sementara sarana upacara yang dipergunakan dalam setiap kegiatan upacara agama Hindu oleh umat biasanya merupakan sarana upacara yang Sukla (bersih dan suci). Dalam Laku hidup sehari hari manusia Bali begitu ketat memilah dualisme suci (Nirmala) dan cemer (Mala), Sakral (Tenget) dan profan (tember), Hulu (ulu) dan Hilir (teben) hingga bersih dan kotor, jernih dan keruh sesuai penerimaan dan pandangan mereka. (Sarad, 2001: 31). Leteh, cemer, kotor, dikonotasikan dengan situasi dan kondisi yang diduga atau dapat diduga tercemar sekala- $n i$ skala akibat terintervensinya ruang dan roang oleh elemen faktor-faktor negatif. (A.A. Ngurah Made Arwata, 2011). Dalam Bahasa Bali leteh artinya sesuatu yang tercemar, tidak suci, menjijikan, maka cuntaka, leteh dikenakan bagi apa saja yang membuat keadaan entah berupa benda hidup, atau entah benda mati. (Sarad: 2001: 29). Problema ini menjadi pembicaraan antara masyarakat pengguna sarana upacara berbahan limbah. Kelayakan dari penggunaan sarana upacara yang berbahan koran bekas ini diragukan oleh konsumen, karena koran bekas atau limbah dianggap kotor. Persoalan ini memang menyangkut pertimbangan rasa manusianya yang tidak sepenuhnya dapat digunakan sebagai pembanding. (Widana, 2012: 88). Namun keraguan 


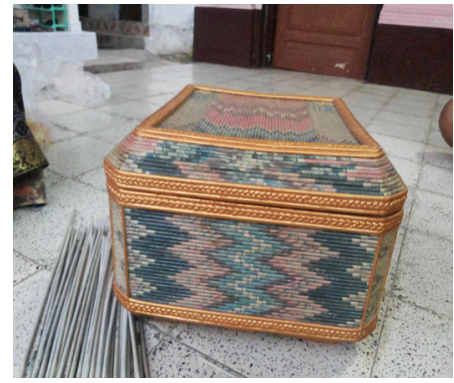

Gambar 1. Bentuk keben dengan warna asli koran sebagai hiasannya

itu sirna ketika sarana upacara ini dapat disucikan dengan memercikan air suci atau penglukatan, sehingga sarana upacara ini menjadi sukla yaitu dalam keadaan bersih dan suci. Dengan adanya upaya ini maka masyarakat pengguna khususnya masyarakat Bali yang beragama Hindu tidak ragu lagi untuk membeli dan menggunakan sarana upacara berbahan koran bekas yang unik, artistik dan estetis.

\section{Dinamika Bentuk Sarana Upacara Berbasis Upcycle.}

Dewasa ini Seni kerajinan sarana upacara berbahan limbah koran memiliki peluang yang sangat besar untuk dikembangkan di tengah masyarakat Bali. Hal ini menjadi peluang yang sangat terbuka bagi para perajin untuk meningkatkan produksi dan memasarkan pada masyarakat konsumen. Berbagai bentuk produk kerajinan sarana upacara telah diciptakan. Berawal dari bentuk yang sangat sederhana yaitu berupa bentuk pemuspaan dan bokoran.

Awal perkembangan produk sarana upacara bentuknya masih sangat sederhana tanpa penerapan ornamen, tampilan ornamen terlihat dari variasi gambar dan warna koran yang dipergunakan dalam membuat produk. Keindahan sebuah bokoran atau pemuspan tidak hanya dapat dilihat dari bentuknya, juga dapat dilihat dari permainan warna warna koran yang membentuk motif motif geometris. Kepiawaian perajin sangat dibutuhkan dalam menyusun lintingan lintingan koran sehingga membentuk sebuah motif. Pengaturan unsur unsur desain seperti, garis, bidang, warna, tekstur selalu menjadi pertimbangan dalam menyusun lintingan lintingan koran sehingga menghasilkan komposisi motif geometris yang estetis. Perajin harus pintar memilih koran yang mempunyai warna warna yang cerah, dipilah dalam satu kelompok terbitan sehingga mendapat warna koran yang sama. Namun hal ini tidaklah mudah dilakukan, karena biasanya koran yang di beli pada pengepul sampah kebanyakan tidak sama jenisnya, sehingga perajin kesulitan dalam penyediaan bahan baku koran dengan warna yang sama.

Perajin yang kreatif tidak pernah putus asa, selalu mempunya ide ide baru untuk menciptakan produk produk baru yang lebih menarik dan indah. Memanfaatkan limbah koran yang ada dengan pengembangan ide ide baru, sehingga menghasilkan bentuk bentuk produk yang lebih bervariatif. Perajin sangat jeli melihat selera masyarakat

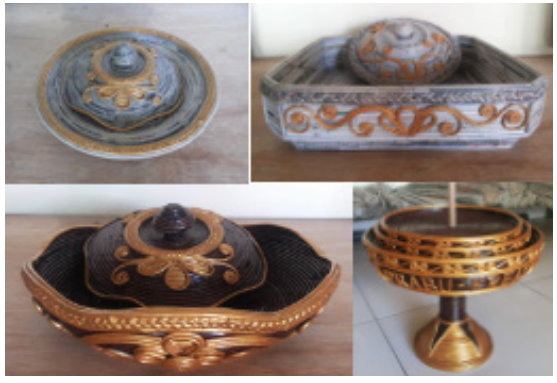

Gambar 2. Beragam bentuk bokoran dan Dulang menggunakan motif sulur suluran.

yang semakin berkembang, oleh sebab itu bentuk bentuk produk kerajinan sarana upacara berbahan limbah koran semakin bervariatif dengan menawarkan berbagai kelebihan, baik model, fungsi, dan penampilan. Perajin mulai membuat berbagai variasi bentuk produk sarana upacara lainnya seperti bokoran dengan berbagai ukuran, tempat pemuspan dengan berbagai macam bentuk, dulang dan keben. Selain ukuran yang bermacam-macam, perkembangan bentuk juga terlihat semakin bervariasi, yang merupakan penggabungan bentuk bokoran dengan keben. Sebuah bokoran biasanya dilengkapi dengan Saab atau tudung saji sebagai penutup sesajen. Sekarang berkembang bentuk bokoran dengan penutup yang ukurannya sama, seperti mirip dengan tokasi atau keben namun bentuknya bulat. Kreatifitas perajin dalam menciptakan produk sarana upacara juga terlihat dengan menambahkan ornamen sebagai dekorasi sehingga produk yang dihasilkan lebih estetis dan artistik. Hal yang sangat menarik adalah pemanfaatan ornamen Bali menjadi suatu yang sangat dominan sebagai penambah keindahan produk. Ornamen menjadi bagian yang sangat penting dalam penciptaan sarana upacara, ini sebagai tanda bahwa orang Bali sangat mencintai seni dan keindahan. Keyakinan masyarakat Bali bahwa sebuah produk akan memiliki nilai seni yang tinggi apabila telah dihiasi dengan ornamen.( Karuni, Suardana, 2019: 103).

Motif motif yang diterapkan dalam produk sarana upacara berawal dari bentuk yang sangat sederhana, berupa Tali ilut, bentuk pilin, dirangkai menjadi bentuk sulur suluran yang harmonis.

Penerapan ornamen pada produk kerajinan sarana upacara seiring waktu semakin berkembang. Perajin kemudian melakukan pengembangan penerapan ornamen tradisional Bali berupa motif kekarangan, seperti karang guak dan karang Sae. Penerapan motif kekarangan pada produk juga disesuaikan dengan bentuk motif. Motif karang guak ditempatkan pada bagian sudut sudut produk seperti pada produk keben berbentuk segi empat dan segi delapan. Demikian juga pada penerapan motif karang sae atau karang boma, penerapan motifnya disesuaikan dengan ruang dan bidang produk, seperti pada bokoran dan keben atau tokasi, sehingga produk menjadi lebih elegan, dan indah.

Pembubuhan ornamen pada sebuah produk tidak semata 


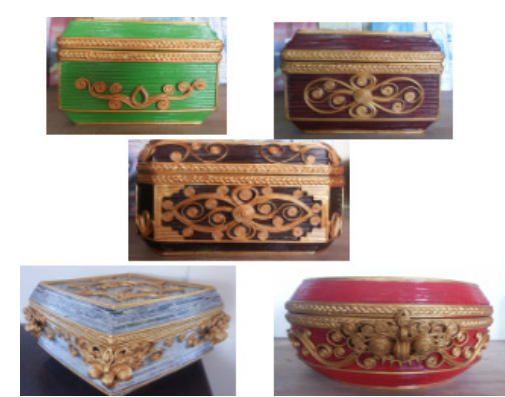

Gambar 3. Dinamika bentuk produk dengan variasi motif pilin, sulur suluran, karang Guak dan karang Sae

penambah keindahan, tetapi juga memberikan nilai yang sangat tinggi, baik secara ekonomi maupun status sosial pemakainya. Semakin rumit ornamen yang diterapkan, harga produk menjadi semakin mahal, karena terkait dengan waktu pengerjaannya yang semakin lama, namun harga masih dapat terjangkau oleh masyarakat. Masyarakat tinggal memilih bentuk dan jenis produk yang diminati dan disesuaikan dengan daya beli masing masing.

\section{Proses Kreatif Perajin Dalam Menciptakan produk Sarana Upacara}

Dalam proses penciptaan bentuk produk seni diperlukan adanya kreativitas dan kemampuan teknik. Franz Boas memandang keterkaitan bentuk dan teknik itu merupakan sesuatu yang selalu mengalami perkembangan sejalan dengan aktivitas manusia, karena alam dipandang tidak memberikan bentuk ideal, kecuali bila diberi sentuhan tangan-tangan terampil (Boas, 1955: 10) Selain itu mutu seni kerajinan ditentukan oleh nilai-nilai keindahan sesuai dengan fungsi gunanya dan nilai yang terkandung dalam kemampuan teknis. Sebagai karya seni, produk kerajinan harus menampilkan nilai estetis atau nilai keindahan rupa, sedangkan sebagai karya seni terapan, nilai estetis karya kerajinan tidak dapat dipisahkan dari nilai gunanya. Kemampuan teknis dalam penciptaan seni kerajinan adalah kemampuan untuk mengenal bahan, artinya mengenal watak bahan, mengolahnya dan mempergunakannya berdasarkan berbagai teknik. Pada seni kerajinan, nilai teknis juga menentukan kualitas karya seninya, maka kemampuan atau ketrampilan teknis dalam seni kerajinan selain merupakan usaha mengeksplotasikan bahan juga untuk menciptakan bentuk yang mampu menjawab fungsi pakainya. Kemampuan teknik itu sendiri harus menjawab tuntutan keindahan dari seni kerajinan, oleh sebab itu perajin sarana upacara yang ada di banjar Pande desa Kediri Tabanan dalam menciptakan produk kerajinan selalu mempertimbangkan nilai fungsi, ergonomis, nilai teknik dan nilai keindahannya.

Proses pembuatan produk sarana upacara diawali dengan pemilihan dan pemilahan koran bekas. Kertas koran yang sering dipergunakan adalah kertas koran yang berwarna warni (koran Kompas , Bali Post, Koran TOKOH, Nusa Bali dan Jawa Pos). Selain karena warnanya lebih cerah, telstur kertasnya lebih liat dan tidak mudah sobek. Bahan

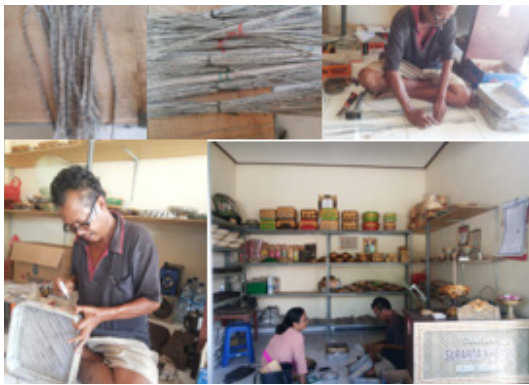

Gambar 4. Proses kreasi perajin dalam membuat produk sarana upacara berbahan koran bekas.

tambahan yang digunakan antara Lem Pox, Lem Alteco, Mowilex, dan pewarna Prada. Apabila bahan dan alat sudah siap langkah selanjutnya adalah menggunting kertas menjadi enam bagian untuk bahan dasar, dan menggunting kertas koran menjadi dua belas bagian untuk membuat lintingan koran sebagai bahan dekorasinya. Koran yang telah digunting dipilin pilin menjadi lintingan koran sesuai ukuran. Langkah selanjutnya lintingan koran dibentuk sesuai bentuk produk yang dibuat. Untuk merekatkan antara lintingan satu koran dengan lintingan koran yang lainnya, dilakukan dengan proses pengeliman tahap demi tahap sehingga membentuk sebuah produk. Apabila tahap pembentukan telah selesai, tahap berikutnya adalah pembuatan dekorasi. Penerapan dekorasi dengan menggunakan teknik tempel dan pilin, disesuaikan dengan motif yang dibuat. Kreatifitas dan kemampuan dalam mengolah lintingan lintingan koran sangat dibutuhkan dalam proses pendekorasian sehingga membentuk sebuah motif yang indah dan menarik. Menurut Suparta, Perajin dari banjar Pande desa Kediri selalu menerapkan ornamen Bali sebagai dekorasinya, dengan pertimbangan karena pangsa pasar atau pengguna dari produk ini kebanyakan masyarakat Bali yang beragama Hindu. Apabila proses pendekorasian telah selesai, tahap berikutnya sebagai tahap akhir proses penciptaan produk sarana upacara adalah proses finishing. Kesempurnaan proses finishing sangat menentukan kualitas sebuah produk. Bahan finishing produk sarana upacara menggunakan cat, prada , mowilek atau clear gloss. Proses finishing dilakukan dengan mengoleskan cat berwarna merah, hijau, coklat, atau warna lainnya pada bagian permukaan produk sesuai keinginan. Ada beberapa produk yang sengaja tidak di cat atau diwarnai dengan tujuan untuk mempertahankan warna asli dari koran, sehingga kelihatan keindahan dari tekstur bahan yang dipergunakan dalam membuat produk. Finishing dekorasi produk menggunakan prada sebagai pewarna, supaya produk sarana upacara kelihatan lebih mewah, estetis, menarik dan elegan. Penggunaan prada warna gold dengan cara dioleskan pada bagian bagian hiasan sesuai keinginan. Apabila tahap pewarnaan telah selesai, dilanjutkan dengan tahap finishing terakhir dengan menyemprotkan clear gloss atau mengoleskan mowilek keseluruh bagian produk sampai rata. Pelapisan dengan clear gloss atau mowilek tujuannya agar produk terlindung dari air dan sinar matahari, karena produk sarana upacara berbahan kertas koran yang mudah 
rusak apabila kena air dan warnanya menjadi kusam kalau sering kena sinar matahari, sehingga tahap pelapisan perlu dilakukan agar produk tahan terhadap air dan sinar matahari.. Selain itu tujuannya supaya produk sarana upacara kelihatan lebih mengkilat serta menjadi lebih awet

\section{SIMPULAN}

Berdasarkan seluruh pembahasan diatas dapat ditarik kesimpulan bahwa produk sarana upacara dibuat dari material pemanfaatan kembali limbah koran menjadi produk baru yang dilakukan masyarakat Desa Kediri Tabanan sesuai dengan salah satu konsep daur ulang yaitu upcycle. Upcycle atau dalam prosesnya disebut upcycling yang merupakan sebuah proses penambahan nilai guna dari material yang sudah dibuang diubah menjadi sesuatu yang lebih bernilai atau berkualitas. Kualitas sebuah produk kerajinan sarana upacara bukan hanya tercermin dari bahan atau material yang digunakan, namun juga muncul dari kecermatan penyusunan unsur-unsur rupa pembentuknya. Setiap karya seni tentu memiliki nilai estetika yang di dalamnya mengandung susunan atau struktur yang merupakan aspek-aspek menyangkut keseluruhan dari karya itu dan meliputi juga peranan masing-masing bagian dalam keseluruhan itu.

Perubahan dan perkembangan produk sarana upacara berbasis upcycle terlihat pada bentuk dan ornamen yang diterapkan. Awal perkembangan produk sarana upacara bentuknya masih sangat sederhana tanpa penerapan ornamen, tampilan ornamen terlihat dari variasi gambar dan warna koran yang dipergunakan dalam membuat produk. Lambat laun Perajin mulai kreatif dalam menciptakan produk sarana upacara dengan menambahkan ornamen tradisional Bali sebagai dekorasi sehingga produk yang dihasilkan lebih estetis dan artistik.

Seni kerajinan sarana upacara berbahan limbah koran berkembang sangat pesat. Berbagai jenis dan bentuk sarana upacara yang unik dan menarik telah tercipta dengan menawarkan berbagai keindahan dan kepraktisan dalam pemakaiannya. Kreatifitas perajin di banjar Pande Desa Kediri Tabanan mengenalkan produk sarana upacara berbahan limbah koran melalui kegiatan ekonomi yang sekaligus menjadi upaya pelestarian lingkungan.

Proses kreasi dalam pemanfaatan koran bekas menjadi beraneka ragam kerajinan sarana upacara dilakukan melalui proses pembentukan, pendekorasian dan tahap finishing. penerapan dekorasi menggunakan teknik pilin dan tempel, finishing menggunakan teknik oles dan semprot. Bentuk produk yang dihasilkan berupa : bokoran, tempat pemuspan, keben, dulang yang fungsinya sebagai wadah atau tempat sesajen. Produk yang dihasilkan merupakan produk kreatif yang ramah lingkungan. Pemanfaatan limbah koran untuk produk kerajinan sarana upacara merupakan suatu upaya untuk mengurangi pencemaran lingkungan.
Selain itu pemanfaatan limbah koran sebagai bahan seni kerajinan dapat meningkatkan nilai tambah dan nilai ekonomi perajin.

\section{DAFTAR RUJUKAN}

Azwar,A.1990. Pengantar Ilmu Kesehatan Lingkungan. Yayasan Mutiara :Jakarta

Boas, Franz. (1955), Primitive Art, Dover Publications, Inc, New York

Gusti Ketut Widana, 2012, Penjor Lebay: Upacara Menjamin Masuk Sorga, Pustaka Bali Post, Denpasar

Gustami SP., 1991, "Seni Kriya Indonesia: Dilema Pembinaan dan Pengembangannya", Pidato Ilmiah pada Dies Natalis VII ISI Yogyakarta.

, 1999, « Jiwa Interprenurship Penting Bagi Kriyawan Menghadapi Millinium III », dalam makalah Sarasehan dalam rangka Pameran Nasional Seni Kriya Menyongsong Millinium III, 10 April, di Galery Ardiyanto, Yogyakarta,

Ismail Alif Siregar, 2015, “ Pemanfaatan Limbah Koran Untuk Pengembangan Material Bahan Fiber" dalam Jurnal Widyakala, Universitas Pembangunan Jaya no2 Volume 2 , Tanggerang selatan, Bnaten

Karma Yudibrata, 1981/1982, « Peranan Seni Dalam Membina Masyarakat di Lingkungan Pendidikan Guru » dalam Majalah Analisis Kebudayaan, th II- no 2, Jakarta, Departemen Pindidikan dan Kebudayaan,

Karuni, Suardana, 2018, "Pengaruh Gaya Hidup Religius Pada Produksi Kerajinan Sarana Upacara Di Bali," dalam Prosseding Seminar Nasional, Seni Dan Nasionalisme, Institut Seni Indonesia, Surakarta.

Karuni, Suardana, Suparta, 2019, "Produksi Kerajinan Sarana Upacara dan Gaya Hidup Religius Masyarakat Gianyar," dalam Jurnal Mudra Volume 34 no 1, Institut Seni Indonesia, Denpasar.

Moleong, Lexy, J, 2013, Metodologi Penelitian Kualitatif, PT Remaja Rosdakarya,

Bandung.

Pradnyani, 2019, « Kain Tenun Ikat Idup Panak Berbasis Upcycle di Desa Tenganan, » Tesis Program Pascasarjana ISI Denpasar.

Sarad, 2001, Majalah Gumi Bali, no 19 juli 2001, yayasan Gumi Bali Denpasar. 
Suprihana, 1997 dalam Yusnita Arvianti, 2016 "Teknologi Daur Ulang Kertas Koran Menjadi Kerajinan Tangan Bernilai Jual Tinggi Dan Analisa Kelayakannya(Studi Kasus Di Kelompok Ibu Rumah Tangga Sekarwangi Malang)”, Jurnal Buana Sains Vol 16 No 2: 129-136, Malang.

Tjetjep Rohendi Rosidi, 2000, Kesenian Dalam Pendekatan Kebudayaan, Bandung, STISI Bandung Press,

Umar Kayam, 1981/1982, « Kreativitas Dalam Seni dan Masyarakat Suatu Demensi Dalam Proses Pembentukan Budaya Dalam Masyarakat » dalam Analisis Kebudayaan, th II-no 1,

\section{Sumber Internet}

Pintu Pandit, Gayatri T. Nadathur, Seiko Jose. " Upcycled And Low-Cost

Sustainable Business For Valueadded Textiles And Fashion". Circular

Economy in Textiles and Apparel (2019), 95-122

$<$ https://doi.org/10.1016/B978-0-08-102630-4.00005-4>

Sung, Kyungeun. “A Review on Upcycling: Current Body of Literature, Knowledge Gaps and a Way Forward”. Venice Italy Apr 13-14, 2015, 17 (4) Part I, 28-40.

$<$ https://www.researchgate.net/publication/299559229_A_Review_on_Upcycli

ng_Current_Body_of_Literature_Knowledge_Gaps and_a_Way_Forward> 